\title{
Properties of particleboards made from sugarcane bagasse particles
}

\author{
Flávia Maria Silva Brito ${ }^{1 *} \oplus$, Geraldo Bortoletto Júnior ${ }^{1} \oplus$, Paula Gabriella Surdi ${ }^{2} \odot$ \\ ${ }^{1}$ Universidade de São Paulo, Escola Superior de Agricultura Luiz de Queiroz, Piracicaba, SP, Brasil. E-mail: faengflorestal@gmail.com; gbjunior@usp.br \\ ${ }^{2}$ Universidade Federal de Viçosa, Laboratório de Painéis e Energia da Madeira, Viçosa, MG, Brasil. E-mail: paulasurdi@gmail.com
}

\begin{abstract}
The objective of this work was to evaluate the physical-mechanical properties and the density profile of panels produced with sugarcane bagasse particles with two sizes $(0.50$ and $0.85 \mathrm{~mm})$ and with pre-treatment (particles treated in hot water at $70{ }^{\circ} \mathrm{C}$ for two hours) and without pre-treatment. The nominal density of the panels was $0.65 \mathrm{~g} \mathrm{~cm}^{-3}$. The cycle parameters were $35 \mathrm{kgf} \mathrm{cm}^{-2}$ of pressure, temperature of $180^{\circ} \mathrm{C}$ and $10 \mathrm{~min}$ of pressing. The physical and mechanical tests were performed according to the requirements of NBR 14810-2006. The density profile of the particleboards was obtained by X-ray densitometry. The water absorption in two hours was higher in the panels produced with particles treated in hot water. The other physical and mechanical properties were not influenced by the evaluated factors. The apparent density varied along the thickness of the panels, with more pronounced peaks in the outer layers, thus presenting a vertical density gradient within the normal range for this type of panel. The physical-mechanical properties do not meet the minimum requirements by the NBR 14810 (2006) for nonstructural panels for indoor use in dry conditions (Type P2).
\end{abstract}

Key words: composites; density profile; dimensional stability; residues

\section{Propriedades de painéis aglomerados constituídos por partículas de bagaço de cana-de-açúcar}

RESUMO: O objetivo deste trabalho foi avaliar as propriedades físico-mecânicas e o perfil de densidade de painéis produzidos com partículas de bagaço de cana-de-açúcar com dois tamanhos $(0.50$ e $0.85 \mathrm{~mm})$ e com pré-tratamento (partículas tratadas em água quente a $70^{\circ} \mathrm{C}$ por duas horas) e sem pré-tratamento. A densidade nominal dos painéis foi $0.65 \mathrm{~g} \mathrm{~cm}^{-3}$. Os parâmetros do ciclo foram $35 \mathrm{kgf} \mathrm{cm}^{-2}$ de pressão, temperatura de $180^{\circ} \mathrm{C}$ e $10 \mathrm{~min}$ de prensagem. Os testes físicos e mecânicos foram realizados de acordo com as designações da NBR 14810-2006. O perfil de densidade dos painéis de partículas foi obtido por densitometria de raio-X. A absorção de água em duas horas foi maior nos painéis produzidos com partículas tratadas em água quente. As demais propriedades físicas e mecânicas não foram influenciadas pelos fatores avaliados. A densidade aparente variou ao longo da espessura dos painéis, com picos mais pronunciados nas camadas externas, apresentando assim um gradiente vertical de densidade dentro da normalidade para este tipo de painel. As propriedades fisicas e mecânicas não atenderam aos requisitos mínimos da NBR 14810 (2006) para painéis não estruturais para uso interno em condições secas (Tipo P2).

Palavras-chave: compósitos; perfil de densidade; estabilidade dimensional; resíduos

\footnotetext{
* Flávia Maria Silva Brito - E-mail: faengflorestal@gmail.com (Corresponding author)

Associate Editor: Rafael Rodolfo de Melo
} 


\section{Introduction}

The particleboards are produced with wood particles and addition of synthetic adhesives under heat and pressure (Araújo et al., 2019). Some features of the panels stand out that make their use interesting, such as low requirement on raw materials, absence of dimensional instability and availability of large pieces. In 2018, Brazil produced 8.2 million $\mathrm{m}^{3}$ of reconstituted panels (Ibá, 2019). The panel quality depends on wood factors, such as species, extractives and basic density, besides those related to processing (Surdi et al., 2019).

The particle geometry is a parameter that can affect the final performance of the panels. This variable influences the physical properties of the panels (Rusch et al., 2020). The particle geometry has a great influence on the final properties of the panel, along with the species of wood, the amount of adhesives and additives. Some mechanical properties can also be affected by geometry such as flexural strength, parallel tensile strength, perpendicular surface resistance and screw pulling resistance (Araújo et al., 2019).

The production of particleboards is supported by raw material from Pinus and Eucalyptus (Sozim et al., 2019). However, the advance of this sector resulted in an increase in demand for raw material for manufacturing products and therefore the need to seek new alternative sources. An interesting alternative would be sugarcane bagasse that is a residue of lignocellulosic fiber derived from sugarcane processing and juice extraction. It is used in the sugar and ethanol industry to generate heat, steam and energy (Mesquita et al., 2019).

In the 2018/19 harvest, Brazil produced approximately 620 million tons of sugarcane, the raw material used to produce 29 million tons of sugar, 33 billion liters of ethanol and 21.5 TWh for the chain national electrical. Most of the bagasse produced is used in the plant itself to generate steam to supply energy to its industrial park. The estimated amount of bagasse generation for one ton of sugar cane is $250 \mathrm{~kg}$ (UNICA, 2020).

Of using waste for manufacturing particleboards made from sugarcane bagasse is important from the social, economic, and business perspectives. Some studies carried out by Mendes et al. (2014), Fiorelli et al. (2016), Soares et al. (2017), Silva et al. (2018), Brito \& Bortoletto Júnior (2019), Buzo et al. (2019) and Nakanishi et al. (2019) have demonstrated that this waste has the potential to produce panels, associated or not, with other lignocellulosic materials. In a study conducted with sugarcane bagasse Soares et al. (2017) observed that this material contains high amounts of extracts, substances that can affect the curing of the resin and the adhesion between particles, in addition to cells with less stiffness and more damaged because of the sugarcane milling process (Mesquita et al., 2017, 2019).

Thus, the objective of this work was to evaluate the physical and mechanical properties and the density profile of particleboard panels produced with sugarcane bagasse particles with two sizes $(0.50$ and $0.85 \mathrm{~mm})$, untreated and treated in hot water.

\section{Materials and Methods}

\section{Particles}

Sugarcane residues (bagasse) free from signs of deterioration and uniform staining were collected from the plant stockyard at a sugar mill located in the city of Santa Bárbara D'Oeste - SP. After the collection the material was transported to the laboratory's yard, where the bagasse was exposed to the open air for natural drying until it reached moisture of close to $18 \%$.

The material was dried in an oven equipped with renovation and forced air circulation at $70{ }^{\circ} \mathrm{C}$ for three hours until reaching an average moisture content of $10 \%$. After, the particles were classified into a vibrating machine and the particles of 0.50 and $0.85 \mathrm{~mm}$ were used for particleboards production, separately.

The density of the sugarcane bagasse particles was 0.090 $\mathrm{g} \mathrm{cm}^{-3}$.

\section{Pretreatment of the particles by immersion in hot water}

A box with dimensions of $63 \times 30 \times 83 \mathrm{~cm}$ (width $\times$ height $\times$ length) was constructed with iron bars and shading screens for the treatment. The particles were packed inside the box and submerged in hot water in a metal tank, equipped with a set of electrical resistors and thermostat set to maintain the temperature of the liquid at $70{ }^{\circ} \mathrm{C}$ for two hours. After this period, the particles were washed away in running water, dried in the open air and in an oven until they reached a moisture content of 3 to $4 \%$, because this is the ideal content for manufacturing particular panels.

\section{Particleboards production}

The adhesive Urea-Formaldehyde (UF) was applied to the particles with a solids content of $64.16 \%$, density of 1.27 $\mathrm{g} \mathrm{cm}^{-3}$ and a $\mathrm{pH}$ of 7.88 , with $10 \%$ of resin solids based on the dry mass of the particles. An ammonia sulfate solution (catalyst) was added to the adhesive at a ratio of $5 \%$ solids. Liquid paraffin at $1 \%$ solids was also applied to the particles in all treatments on the same basis as the adhesive.

The particles impregnated with adhesive and paraffin were manually placed into a mattress-forming wooden box with internal dimensions of $40 \times 40 \mathrm{~cm}$.

The particulate-mat was placed in a hydraulic press for hot pressing. The maximum pressure used during the panels pressing was $35 \mathrm{kgf} \mathrm{cm}^{-2}$ at a temperature of $180{ }^{\circ} \mathrm{C}$ and total time of $10 \mathrm{~min}$ using $15.70 \mathrm{~mm}$ thickness separators.

After cooling, the particleboards were conditioned in an air-conditioned room with controlled temperature and relative humidity at $22 \pm 2{ }^{\circ} \mathrm{C}$ and $65 \pm 5 \%$, respectively, until constant mass, indicating that they reached the equilibrium moisture content with the environment.

\section{Properties of the particleboards}

The apparent density, moisture content, water absorption and thickness swelling after 2 and 24 hours of immersion, modulus of rupture and modulus of elasticity to static bending 
and resistance to perpendicular traction (internal bonding) were the properties evaluated in physical-mechanical tests. Specimen dimensions, test realization and property value calculations complied with the requirements of Brazilian Norm - NBR 14810 (ABNT, 2006).

The compaction ratio of the panels was calculated by the ratio between the nominal density of the panel $\left(\mathrm{g} \mathrm{cm}^{-3}\right)$ and the basic density of the sugarcane bagasse $\left(\mathrm{g} \mathrm{cm}^{-3}\right)$.

\section{Density profile of panels}

A QDP-01X QMS X-ray densitometer was used to analyze the density profile. The samples were transferred to the internal compartment of the densitometer, and automatic calibration of the equipment was started for $60 \mathrm{~s}$. Next, continuous scanning along the sample thickness began. The X-ray beams were subsequently transformed into specific density point values obtained every $20 \mu \mathrm{m}$ by the QMS program. A file was generated in DAT format from collecting these data and read by Excel software, which allowed for constructing a profile graph of the maximum, medium and minimum apparent densities (Brito \& Bortoletto Júnior, 2020).

\section{Experimental design and statistical analysis}

A completely randomized experimental design was used with a $2 \times 2$ factorial design for the treatments, in which the factors were the bagasse particle size $(0.50$ and $0.85 \mathrm{~mm})$, and the particle treatment (treated and untreated in hot water), totaling 4 treatments and 3 replications. The Tukey test $(p<$ 0.05 ) was applied to the significant factors of the $F$ test $(p<$ 0.05 ) for physical-mechanical properties of the particleboards.

Lilliefors and Cochran tests checked the normality of the data and homogeneity of the variances, respectively. The statistical analyses were performed with Sisvar software. The physical and mechanical test results were compared with those established by NBR 14810 (ABNT, 2006) for the characterization of particleboards for medium density, nonstructural, indoor use in dry conditions (Type P2). The density profile of the particleboards was evaluated by graphic and digital images.

\section{Results and Discussion}

\section{Physical properties}

There was no influence of treatments on the physical properties tested, according to the analysis of variance performed, except for AA2h, which will be discussed in Table 2 . The nominal compaction ratio obtained from the panels was 7.22 and the effective was 6.66 . For panels constituted with granulometry 0.50 and $0.85 \mathrm{~mm}$ the apparent density varied between 0.59 to $0.60 \mathrm{~g} \mathrm{~cm}^{-3}$ and moisture content ranged from 9.22 to $9.83 \%$, respectively (Table 1 ).

The apparent density obtained were lower in all treatments than the calculated nominal density $\left(0.65 \mathrm{~g} \mathrm{~cm}^{-3}\right)$. This fact can be associated with loss of adhesive and paraffin from the initial stages, during the formation of the mattress, scattering of particles in the moldduring pre-pressing, hot pressing stages, and conditioning, with a consequent increase in the volume of the panels and reduction of density initial nominal (Guimarães et al., 2016; Bazzetto et al., 2019). The overall apparent mean density of the panels for all treatments was $0.60 \mathrm{~g} \mathrm{~cm}^{-3}$. Thus, they can be classified as medium density panels, as recommended by NBR 14810 (ABNT, 2006), which comprise panels with densities between 0.55 and $0.75 \mathrm{~g} \mathrm{~cm}^{-3}$. This classification is essential, as minimum values of MoR, $\mathrm{MoE}, \mathrm{IB}$ and TS are directly related to the density (Fiorelli et al., 2016).

The basic density of the sugarcane bagasse particles was $0.090 \mathrm{~g} \mathrm{~cm}^{-3}$, a value similar to that reported by Soares et al. (2017). Thus, the compression ratio was high (7.22) because is related directly with basic density of the material. The literature recommends values in the range between 1.3 and 1.6 , so the value obtained was about four times higher than recommended.

All treatments showed that the mean values of moisture content were below $12 \%$ and there was no significant difference between treatments (Table 1 ). A reduction of hygrocopicity results from the transformation of particulate lignocellulosic material, the addition of adhesive, additives, pressure and temperature used during the production process of the panels (Wu, 1999). The NBR 14810 (ABNT, 2006) stipulates a range between 5 and $11 \%$ as acceptable for the moisture content of particleboard. Therefore, it is observed that all mean values of moisture content meet this requirement.

The WA2h mean values of the particleboards differed in relation to the treatment in hot water, but no differences were found in granulometry (Table 2). The water absorption of the panels produced with treated particles was higher than untreated. It is highlighted that the thermal expansion suffered

Table 1. Apparent density (AD) and moisture content (MC) of the particleboards.

\begin{tabular}{ccccc}
\hline \multirow{2}{*}{$\begin{array}{c}\text { Granulometry } \\
(\mathrm{mm})\end{array}$} & \multicolumn{2}{c}{$\mathrm{AD}\left(\mathrm{g} \mathrm{cm}^{-3}\right)$} & \multicolumn{2}{c}{ MC (\%) } \\
\cline { 2 - 5 } & Untreated & Treated & Untreated & Treated \\
\hline 0.50 & $0.60 \mathrm{aA}$ & $0.59 \mathrm{aA}$ & $9.20 \mathrm{aA}$ & $9.80 \mathrm{aA}$ \\
0.85 & $0.59 \mathrm{aA}$ & $0.60 \mathrm{aA}$ & $9.70 \mathrm{aA}$ & $9.70 \mathrm{aA}$ \\
\hline
\end{tabular}

*Means followed by the same capital letter, per line, or the same lowercase letter, per column, do not differ by the Tukey test $(p>0.05)$. Averages indicated in the columns refer to the granulometry. Averages indicated in the lines refer to particle treatments.

Table 2. Water absorption in 2 hours (WA2H) and 24 hours (WA24H) of the particleboards.

\begin{tabular}{ccccc}
\hline $\begin{array}{c}\text { Granulometry } \\
(\mathrm{mm})\end{array}$ & \multicolumn{2}{c}{ Water absorption 2 hours (\%) } & \multicolumn{2}{c}{ Water absorption 24 hours (\%) } \\
\cline { 2 - 5 } & Untreated & Treated & Untreated & Treated \\
\hline 0.50 & $68.5 \mathrm{aA}$ & $103.5 \mathrm{aB}$ & $138.2 \mathrm{aA}$ & $135.8 \mathrm{aA}$ \\
0.85 & $66.8 \mathrm{aA}$ & $97.7 \mathrm{aB}$ & $133.5 \mathrm{aA}$ & $139.9 \mathrm{aA}$ \\
\hline
\end{tabular}

*Means followed by the same capital letter, per line, or the same lowercase letter, per column, do not differ by the Tukey test ( $p>0.05)$. Averages indicated in the columns refer to the granulometry. Averages indicated in the lines refer to particle treatments. 
by the particles due to the treatment temperature may have produced internal spaces that provided a higher water absorption rate. The values of WA24h of the particleboards varied from 133.5 to $139.9 \%$, but the factors did not have influence in this property.

The WA2h value of the panels produced with hot water treated particles was significantly higher than those panels produced with untreated particles. The water can cause swelling, inducing a movement of the structural components of the panel, breaking the bonding among adhesive and wood surface sites due to mechanical forces and stresses (Liu et al., 2008), creating more porosity for water entrance (Mesquita et al., 2019). The panels produced with hot water treated particles and immersed for 24 hours were statistically equivalent in all treatments. The difference of absorption between 2 and 24 hours can be explained as a function of the paraffin efficiency that acts as a waterproofing agent only in the first two hours of immersion.

Brito et al. (2020) worked with bamboo panels and sugarcane bagasse. Adopted a nominal density of $0.65 \mathrm{~g} \mathrm{~cm}^{-3}$ and nominal thickness of $15.70 \mathrm{~mm}$. Employed $10 \%$ of resin solids content in relation to the dry mass of the adhesive particles based on UF and $1 \%$ of paraffin emulsion. The parameters adopted were $35 \mathrm{kgf} \mathrm{cm}^{-2}, 180^{\circ} \mathrm{C}$ and $10 \mathrm{~min}$. For panels made with only sugarcane bagasse, the authors found $50.00 \%$ and $140.50 \%$ for AA2h and AA24h, respectively.

The TS2 $h$ and TS24h mean values varied from 25.48 to $35.30 \%$ and 40.91 to $47.87 \%$, respectively (Table 3 ), with no differences between the factors evaluated. There was a tendency of the panels with smaller particle size to present lower values for TS2h and TS24H.

Mendes et al. (2014) found 4.5 and $17.8 \%$ for TS2h and TS24h. Brito et al. (2020) obtained average values of 14.41 and $44.75 \%$ for panels made up of bagasse only for TS2 $h$ and TS24h, respectively.

In general, the values obtained in the present study were higher than those reported in the literature, but some factors such as particle size, adhesive solids content, particle moisture at the time of manufacture of the panels and particle mattress humidity may explain, in part, the difference observed.
One of the major obstacles in relation to the use of sugarcane bagasse in manufacturing reconstituted particleboards is related to dimensional instability. None of the treatments met the maximum value $(8 \%)$ specified by the NBR for TS2H.

\section{Mechanical properties}

The MoR values to the static bending of the particleboards varied between 12.87 to $15.51 \mathrm{MPa}$ (Table 4). There were not statistic differences between the factors, but the panels with $0.85 \mathrm{~mm}$ granulometry presented higher values than those of $0.50 \mathrm{~mm}$. The MoE values to the static bending of the particleboards varied between 692.58 to $849.14 \mathrm{MPa}$ (Table 4). There was not statistic difference between the factors, but the panels treated in hot water presented higher values than those untreated in each granulometry. The internal bonding was similar between the treatments, presenting values from 0.16 to $0.23 \mathrm{MPa}$ (Table 4).

For mechanical properties, there was no significant difference between treatments for the tested factors. The modulus of rupture values were compatible with those reported in the literature. Mendes et al. (2014) found 12.5 MPa and Brito et al. (2020) obtained 11.77 MPa. Panels with higher compaction rates can damage the particles, reducing their resistance and causing a reduction in the mechanical properties of the panels (Milagres et al., 2019). The panels evaluated did not reached the $16 \mathrm{MPa}$ value stipulated by standard as minimum value for the modulus of rupture. Considering the high compression ratio of the material, this occurred because of the large surface area of the sugarcane bagasse particles that were not sufficiently covered by the adhesive content used.

The MoE values were lower than the literature data. Mendes et al. (2014) found 2.095,00 MPa and Brito et al. (2020) obtained 1096.57 MPa. These researchers worked with the same material (sugarcane bagasse) in addition to bamboo and performed measurements of these particles. They noticed that the longer and thinner ones had higher values of static bending, when compared to the bamboo particles, which were smaller and thicker. The standard utilized NBR

Table 3. Thickness swelling in 2 hours (TS2H) and 24 hours (TS24H) of the particleboards.

\begin{tabular}{ccccc}
\hline $\begin{array}{c}\text { Granulometry } \\
(\mathrm{mm})\end{array}$ & \multicolumn{2}{c}{ Thickness swelling $\mathbf{2}$ hours (\%) } & \multicolumn{2}{c}{ Thickness swelling 24 hours (\%) } \\
\cline { 2 - 5 } & Untreated & Treated & Untreated & Treated \\
\hline 0.50 & $25.4 \mathrm{aA}$ & $31.0 \mathrm{aA}$ & $41.8 \mathrm{aA}$ & $40.9 \mathrm{aA}$ \\
0.85 & $32.2 \mathrm{aA}$ & $35.3 \mathrm{aA}$ & $46.8 \mathrm{aA}$ & $47.8 \mathrm{aA}$ \\
\hline
\end{tabular}

*Means followed by the same capital letter, per line, or the same lowercase letter, per column, do not differ by the Tukey test ( $p>0.05$ ). Averages indicated in the columns refer to the granulometry. Averages indicated in the lines refer to particle treatments.

Table 4. Modulus of rupture (MoR) and modulus of elasticity (MoE) to the static bending and internal bond (IB) of the particleboards.

\begin{tabular}{ccccccc}
\hline \multirow{2}{*}{$\begin{array}{c}\text { Granulometry } \\
(\mathbf{m m})\end{array}$} & \multicolumn{2}{c}{ Modulus of rupture $(\mathrm{MPa})$} & \multicolumn{2}{c}{ Modulus of elasticity (MPa) } & \multicolumn{2}{c}{ Internal bonding (MPa) } \\
\cline { 2 - 7 } & Untreated & Treated & Untreated & Treated & Untreated & Treated \\
\hline 0.50 & $13.50 \mathrm{aA}$ & $12.87 \mathrm{aA}$ & $692.58 \mathrm{aA}$ & $798.64 \mathrm{aA}$ & $0.23 \mathrm{aA}$ & $0.22 \mathrm{aA}$ \\
0.85 & $15.51 \mathrm{aA}$ & $13.66 \mathrm{aA}$ & $718.07 \mathrm{aA}$ & $849.14 \mathrm{aA}$ & $0.20 \mathrm{aA}$ & $0.16 \mathrm{aA}$ \\
\hline
\end{tabular}

*Means followed by the same capital letter, per line, or the same lowercase letter, per column, do not differ by the Tukey test ( $p>0.05$ ). Averages indicated in the columns refer to the granulometry. Averages indicated in the lines refer to particle treatments. 
14810 (ABNT, 2006) does not limit values for the modulus of elasticity to static bending.

There was a tendency of decreasing internal bond values for the particleboards produced with a particle size of 0.85 $\mathrm{mm}$. It is presumed that this tendency may have been due to the greater amount of voids resulting from the larger particle size which in turn results in a smaller contact area between particles, a lower number of adhesive bonds and lower resistance values.

The mean value obtained in this study is below the values reported in the literature. Mendes et al. (2014) found $0.46 \mathrm{MPa}$ and Brito et al. (2020) obtained 0.15 MPa. The low internal bond values obtained in this work are possibly related to the adhesive content applied to the particles and may not have been enough to cover the total specific area of the particles, resulting in poor bonding quality. The standard NBR 14810 (ABNT, 2006) stipulates a minimum value of $0.35 \mathrm{MPa}$ for internal bond, thus none of the treatments reached it.

\section{Density profile}

The apparent density of the outer layer was higher in the treated panels in hot water and $0.50 \mathrm{~mm}$ particles (Table 5). The panels produced with $0.85 \mathrm{~mm}$ particles untreated presented higher values of apparent density than those with particles treated. The granulometry also affected this property in the panels untreated.

The values of apparent density of the panels' central layer were similar showing values between 0.58 and $0.59 \mathrm{~g}$ $\mathrm{cm}^{-3}$ (Table 4). The density profiles of the panels constituted with sugarcane bagasse obtained by $\mathrm{X}$-ray images for each treatment are shown in Figure 1.

The panels produced with control particles of $0.85 \mathrm{~mm}$ particle size evidenced a significant increase in the density of the outer layer. This result can be partly explained by the geometry and accommodation of the particles which may have resulted in larger amounts of void spaces and generated a higher mattress.

It was verified that the outer layer of the panels constituted with particles of $0.85 \mathrm{~mm}$ particle size showed more pronounced peaks, confirming the higher mean value obtained because of the interaction analysis. The densities observed on the particleboard faces result due to the effect of the heating of the plates and greater pressures applied at the moment of forming in the press, with the curing of the resin (Brito et al., 2020).

Table 5. Apparent density obtained by X-ray densitometry of the outer and central layers of the particleboards.

\begin{tabular}{ccccc}
\hline \multirow{2}{*}{$\begin{array}{c}\text { Granulometry } \\
(\mathrm{mm})\end{array}$} & \multicolumn{2}{c}{ Outer layer $\left(\mathrm{g} \mathrm{cm}^{-3}\right)$} & \multicolumn{2}{c}{ Central layer $\left(\mathrm{g} \mathrm{cm}^{-3}\right)$} \\
\cline { 2 - 5 } & Untreated & Treated & Untreated & Treated \\
\hline 0.50 & $0.57 \mathrm{aA}$ & $0.62 \mathrm{aB}$ & $0.59 \mathrm{aA}$ & $0.58 \mathrm{aA}$ \\
0.85 & $0.84 \mathrm{bB}$ & $0.61 \mathrm{aA}$ & $0.59 \mathrm{aA}$ & $0.58 \mathrm{aA}$ \\
\hline
\end{tabular}

*Means followed by the same capital letter, per line, or the same lowercase letter, per column, do not differ by the Tukey test $(p>0.05)$. Averages indicated in the columns refer to the granulometry. Averages indicated in the lines refer to particle treatments.
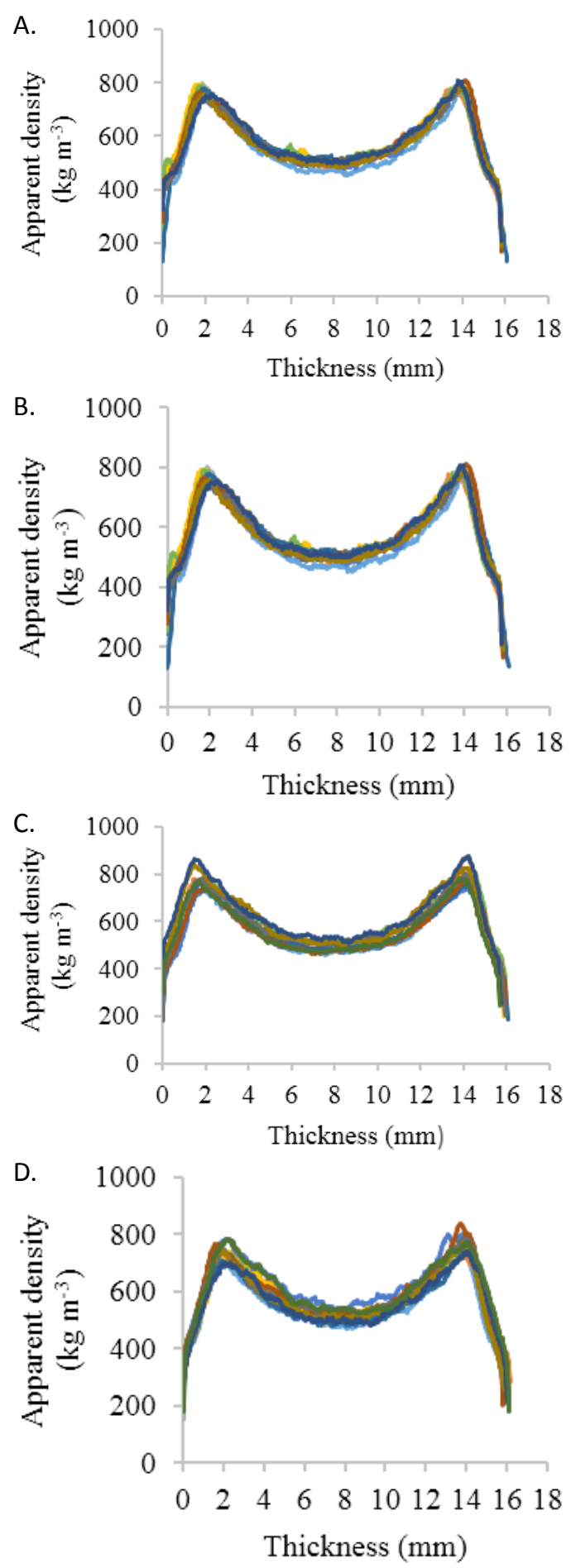

Figure 1. Density profiles of particleboard panels produced with sugarcane bagasse: (A) Particleboards with a particle size of $0.50 \mathrm{~mm}$ (untreated); (B) Particleboards with a particle size of $0.50 \mathrm{~mm}$ (treated in hot water); (C) Particleboards with particle size $0.85 \mathrm{~mm}$ (untreated); (D) Particleboards with a particle size of $0.85 \mathrm{~mm}$ (treated in hot water).

The shape of the apparent density profile observed on each particleboard was similar to the letter " $\mathrm{M}$ ", indicating the density varying along the thickness of the panels. The same format of the graph was observed in other experimental studies with agglomerated panels (Brito \& Bortoletto Júnior 2019, 2020; Brito et al., 2020) 


\section{Conclusions}

The particle size does not significantly influence the physical and mechanical properties of the panels. The particle pretreatment in hot water only influenced the WA2h property, which the panels constituted with treated particles showed a higher mean value.

The density profile of the outer layer of the panels was interactively influenced by the factors, and the $0.85 \mathrm{~mm}$ particle size and the untreated particles resulted in a profile with more pronounced peaks on the panel faces.

The results obtained does not reach the minimum values stipulated by NBR 14810 (2006).

\section{Acknowledgements}

The authors thank the sugar mill Furlan S.A by the donation of the residue and SI Group Crios Resinas S.A., by the donation of the adhesive.

\section{Compliance with Ethical Standards}

Funding: Coordenação de Aperfeiçoamento de Pessoal de Nível Superior - Brasil (CAPES) - Finance Code 001.

Conflict of interest: The authors declare that there is no conflict of interest (professional or financial) that can influence the publication of the article.

Author contribution: Conceptualization: GBJ, FMSB; Data Curation: FMSB, PGS; Formal analysis: FMSB, PGS; Funding acquisition: PGS, FMSB, PGS; Investigation: FMSB, PGS; Methodology: FMSB, PGS; Project administration: GBJ, FMSB; Resources: GBJ; Supervision: GBJ, FMSB; Validation: FMSB; Visualization: FMSB, PGS; Writing - original draft: FMSB; Writing - review \& editing: FMSB, PGS.

\section{Literature Cited}

Araújo, C. K. C.; Campos, C. I.; Camargo, S. K. C. A.; Camargo, B. S. Caracterização mecânica de painéis particulados de média densidade produzidos a partir de resíduos de madeira. Revista Gestão Industrial, v. 15, n. 1, p. 197-211, 2019. https://doi. org/10.3895/gi.v15n1.9159.

Associação Brasileira de Normas Técnicas - ABNT. NBR 14810: chapas de madeira aglomerada. Parte 3: métodos de ensaio. Rio de Janeiro: ABNT, 2006. 51p.

Bazzetto, J. T. L.; Bortoletto Junior, G.; Brito F. M. S. Effect of particle size on bamboo particle board properties. Floresta e Ambiente, v. 26, n.2, e20170125, 2019. https://doi.org/10.1590/2179-8087.012517.

Brito, F. M. S.; Bortoletto Júnior, G. Properties of particleboards manufactured from bamboo (Dendrocalamus asper). Revista Brasileira de Ciências Agrárias, v. 15, n.1, e7245, 2020. https:// doi.org/10.5039/agraria.v15i1a7245.

Brito, F. M. S.; Bortoletto Júnior, G. Thermal modification of sugarcane waste and bamboo particles for the manufacture of particleboards. Revista Árvore, v. 43, n. 1, e430112, 2019. https:// doi.org/10.1590/1806-90882019000100012.
Brito, F. M. S.; Bortoletto Júnior, G.; Paes, J. B.; Belini, U.L.; TomazelloFilho, M. Technological characterization of particleboards made with sugarcane bagasse and bamboo culm particles. Construction and Building Materials, v. 262, e120501, 2020. https://doi. org/10.1016/j.conbuildmat.2020.120501.

Buzo, A. L. S. C.; Sugahara, E. S.; Silva, S. A. M.; Morales, E. A. M.; Azambuja, M. A. Painéis de pinus e bagaço de cana empregandose dois adesivos para uso na construção civil. Ambiente Construído, v. 19, n. 4, p. 183-193, 2019. https://doi.org/10.1590/ s1678-86212019000400350.

Fiorelli, J.; Sartoria, D. L.; Cravo, J. C. M.; Savastano Júnior, H.; Rossignolo, J. A.; Nascimento, M. F.; Lahr, F. A. R. Sugarcane bagasse and castor oil polyurethane adhesive-based particulate composite. Materials Research, v. 16, n. 2, p. 439-446, 2016 https://doi.org/10.1590/S1516-14392013005000004.

Guimarães Júnior J. B.; Xavier M. M.; Santos T. S.; Protásio, T. P.; Mendes, R. F.; Mendes, L. M. Inclusão de resíduo da cultura de sorgo em painéis aglomerados de eucalipto. Pesquisa Florestal Brasileira, v. 36, n. 88, p. 435 - 442, 2016. https://doi. org/10.4336/2016.pfb.36.88.1036.

Indústria Brasileira de Árvores - Ibá. Relatório Ibá. Brasília: Ibá, 2019. 80 p. https://iba.org/datafiles/publicacoes/relatorios/ibarelatorioanual2019.pdf. 22 Jun. 2020.

Liu, Y.Q.; Tian, Y.; Zhao, G. Z.; Sun, Y. Y.; Zhu, F. T.; Cao, Y. Synthesis of urea-formaldehyde resin by melt condensation polymerization. Journal of Polymers Research, v. 15, n. 6, p. 501 - 505, 2008. https://doi.org/10.1007/s10965-008-9194-2.

Mendes, R. F.; Mendes, L. M.; Oliveira, S. L.; Freire, T. P. Use of sugarcane bagasse for particleboard production. Key Engineering Materials, v. 634, p. 163 - 171, 2014. https://doi.org/10.4028/ www.scientific.net/KEM.634.163.

Mesquita, R. G. A.; César, A. A. D. S.; Mendes, R. F.; Mendes, L. M.; Marconcini, J. M.; Glenn, G.; Tonoli, H. D. Polyester composites reinforced with corona-treated fibers from pine, eucalyptus and sugarcane bagasse. Journal of Polymers and the Environment, v. 25 , p. $800-811$, 2017. https://doi.org/10.1007/s10924-0160864-6.

Mesquita, R. G. A.; Sanadi, A. R.; Marconcini, J. M.; Correa, A. C.; César, A. A. D. S.; Andrade, L. M. F.; Lopes, T. A.; Simão, J. A.; Mendes, L. M. The effect of cellulose nanocrystals in sugarcane bagasse particleboards of pith and fibers. Cerne, v. 25, n. 2, p. 203 - 213, 2019. https://doi.org/10.1590/010477602019250226 21.

Milagres, Emerson Gomes, Barbosa, Raiana Augusta Grandal Savino, Caiafa, Karine Fernandes, Gomes, Gabriel Soares Lopes, Castro, Tatiana Aurora Condezo, \& Vital, Benedito Rocha. (2019). Properties of particleboard panels made of sugarcane particles with and without heat treatment. Revista Árvore, v. 43, n. 5, e430502, 2019. https://doi.org/10.1590/180690882019000500002

Nakanishi, E. Y.; Cabral, M.R.; Fiorelli, J.; Santos, V.; Christoforo, A. L.; Savastano Junior, H. Study of the production process of 3-layer sugarcane-bamboo-based particleboards, Construction and Building Materials, v. 183, p. 618 - 625, 2018. https://doi. org/10.1016/j.conbuildmat.2018.06.202. 
Rusch, F.; Mustefaga, E. C.; Hillig, E.; Trevisan, R.; Teleginski, E. Propriedades físicas de painéis de alta densidade (HDP) de pinus, bambu e coparticipação de erva-mate. Research, Society and Development, v. 9, n. 7, e436974022, 2020. https://doi. org/10.33448/rsd-v9i7.4022.

Silva, M. R.; Pinheiro, R. V.; Christoforo, A. L.; Panzerad, T. H.; Lahr, F. A. R. Hybrid sandwich particleboard made with sugarcane, Pinus taeda thermally treated and malva fibre from Amazon. Materials Research, v. 21, n. 1, e20170724, 2018. https://doi. org/10.1590/1980-5373-mr-2017-0724.

Soares, S. S.; Guimarães Júnior, J. B.; Mendes, L. M., Mendes, R. F.; Protasio, T. P.; Lisboa, F. N. Valorização do bagaço de cana-deaçúcar na produção de painéis aglomerados de baixa densidade. Ciência da Madeira, v. 8, n. 2, p. 64 - 73, 2017. https://doi. org/10.15210/cmad.v8i2.10589.
Sozim, P. C. L.; Napoli, L. M.; Ferro, F. S.; Mustefaga, E. C.; Hillig, E. Propriedades de painéis aglomerados produzidos com madeiras de Ligustrum lucidum e Pinus taeda. Pesquisa Florestal Brasileira, v. 39, e201801696, 2019. https://doi.org/10.4336/2019.pfb.39e201801696.

Surdi, P. G.; Bortoletto Júnior, G.; Castro, V. R.; Brito, F. M. S.; Berger, M. S.; Zanuncio, J. C. Particleboard production with residues from mechanical processing of Amazonian woods. Revista Árvore, v. 43, n. 1, e430102, 2019. https://doi.org/10.1590/1806-90882019000100002.

União Das Indústrias de Cana-de-Açúcar - UNICA. A UNICA é a maior organização representativa do setor de açúcar e etanol do Brasil. http://www.unica.com.br. 17 Feb. 2020.

$\mathrm{Wu}, \mathrm{Q}$. Application of Nelson's sorption isotherm to wood composities and overlays. Wood and Fiber Science, v. 31, n. 2, p. 187-191, 1999. https://wfs.swst.org/index.php/wfs/article/view/860/860. 22 Jun. 2020. 